\title{
Biogeochemical effects of macroalgal decomposition on intertidal microbenthos: a microcosm experiment
}

\author{
E. García-Robledo, A. Corzo*, J. García de Lomas, S. A. van Bergeijk \\ Departamento de Biología, Facultad de Ciencias del Mar y Ambientales, Pol. Río San Pedro s/n, 11510 Puerto Real, Spain
}

\begin{abstract}
The decomposition of macroalgal detritus (tubular and planar Ulva spp.) was studied in a microcosm under a daily light:dark cycle to simulate the decomposition on intertidal sediment. The consequences of bloom decay were evaluated in the bulk water phase and in the sediment. Inorganic nutrients $\left(\mathrm{NO}_{3}{ }^{-}, \mathrm{NO}_{2}{ }^{-}, \mathrm{NH}_{4}{ }^{+}, \mathrm{PO}_{4}{ }^{3-}\right.$ and $\left.\mathrm{SiO}_{3}{ }^{2-}\right)$, dissolved organic carbon (DOC) and inorganic carbon (DIC) were measured in the inflowing and outflowing seawater. Vertical microprofiles of $\mathrm{O}_{2}, \mathrm{pH}$ and $\mathrm{H}_{2} \mathrm{~S}$ at the sediment-water interface, sediment contents of organic matter $(\mathrm{OM})$, inorganic and organic carbon $\left(\mathrm{C}_{\text {org }}\right)$, total nitrogen $(\mathrm{N})$ and inorganic nutrients were measured before and after addition of macroalgal detritus. Changes in the taxonomic composition of microphytobenthos were studied by optical microscopy and by the analysis of photosynthetic pigments. Macroalgal detritus vanished from the sediment surface in $6 \mathrm{~d}$. Macroalgal decomposition shifted the microcosm net balance to higher releases of DOC, DIC and inorganic nutrients, suggesting rapid release from macroalgal biomass. Besides being released to the water column, a fraction of macroalgal carbon and of nitrogen was incorporated into the sediment as indicated by a transient increase in $\mathrm{C}_{\text {org }}$ and $\mathrm{N}$. Aerobic mineralization of macroalgal detritus reduced $\mathrm{O}_{2}$ in the water column and the sediment. Microbenthos photosynthetic activity was initially suppressed but recovered from the third day as macroalgal detritus decomposed. Photosynthetic $\mathrm{O}_{2}$ production by microbenthos largely determined the fraction of macroalgal detritus that was aerobically mineralised. Decomposition of macroalgal detritus favoured the dominance of cyanobacteria over diatoms in the microbenthos.
\end{abstract}

KEY WORDS: Macroalgal blooms · Microbenthos · Microelectrodes · Macroalgal decomposition · Macroalgal detritus

\section{INTRODUCTION}

The progressive increase in opportunistic green macroalgal blooms is one of the most visible signs of eutrophication in coastal marine environments (Valiela et al. 1997). In temperate regions, the development of macroalgal blooms occurs mainly in spring and the bloom usually collapses and degrades in summer. Hypoxic or anoxic conditions occur frequently due to the remineralization of the bloom, leading to the accumulation of toxic sulphides and faunal mortality (Viaroli et al. 2001). Most studies have focused on the ecological conditions that trigger blooms and the impact of live mats on different ecosystem compartments and functions (Valiela et al. 1997).
Studies on bloom decay are scarce and they have focused on the decomposition of macroalgal tissue itself and also its effects in the water column, using a variety of methodological approaches. Studies of biomass losses during in situ incubations of live or frozen and thawed macroalgae in litter bags have demonstrated that macroalgae degrade faster than seagrasses and higher plants (likely due to their higher N-content), releasing both inorganic nutrients and organic $\mathrm{N}$ (Williams 1984, Buchsbaum et al. 1991, Bourgues et al. 1996). Regeneration of carbon and nitrogen in the dark has also been studied in laboratory experiments using live or pre-frozen macroalgae in oxic (Castaldelli et al. 2003) or anoxic conditions (Williams 1984, Bourgues et al. 1996). A study of decomposition of ${ }^{14} \mathrm{C}$-labelled 
Ulva rigida showed the existence of a phase of quick release of DOC during the first 15 min that was independent of bacterial activity, followed by a phase (that lasted days) of slower release dependent on bacterial activity (Castaldelli et al. 2003). Interestingly, production of organic volatile compounds during the decomposition process has been suggested (Castaldelli et al. 2003). Those experiment, either in situ or in the laboratory, focussed mainly on the time course of weight loss and chemical changes that occurred in the macroalgal detritus, excluding the interaction with the sediment during the decomposition process. However, decomposition frequently occurs in close contact with the sediment.

The degradation of a large amount of frozen and thawed macroalgal detritus $\left(80 \mathrm{~kg} \mathrm{FW} \mathrm{m}^{-2}\right)$ in a closed mesocosms system containing a sediment layer was studied by Nedergaard et al. (2002). This system was exposed to low irradiance and quickly evolved to anoxia. Under these conditions (that typically occur in dense blooms) up to $90 \%$ of the system-integrated sulphate reduction occurs in the water column through the metabolism of thallus-associated sulphate reducers. Lomstein et al. (2006) used flow-through microcosms to quantify the nutrient and carbon release during decomposition from a macroalgae-sediment system in dark. This study confirmed the colonization of the thalli by bacteria during the decomposition process, with sulphate reducers responsible for $3 \%$ of carbon oxidation. However, sulphate reduction rates were always higher in the sediment below the macroalgae mat. The increase in $\mathrm{C}: \mathrm{N}$ ratio of mineralization products (Pedersen et al. 1999) suggests that mineralised nitrogen (mainly $\mathrm{NH}_{4}^{+}$) from the macroalgal detritus is incorporated into the bacterial biomass (Lomstein et al. 2006).

Decomposition of macroalgal blooms frequently occurs on shallow photic sediment inhabited by microphytobenthos. The degradation of macroalgal detritus is likely to affect considerably the different biogeochemical processes at the sediment-water interface. Photosynthetic activity of microphytobenthos may account for a large fraction of total primary production in estuaries and shallow environments (Underwood \& Kromkamp 1999) and is an important carbon source for benthic heterotrophs (Middelburg et al. 2000). Similarly, biological activities of microbenthos play an important role in oxygen and nutrient exchange at the sediment-water interface, and therefore greatly affect the mineralization of organic matter and the biogeochemical cycling of elements in shallow environments (Risgaard-Petersen 2003 and references therein). Previous studies have considered the effects of live macroalgal mats on microbenthos (Sundbäck et al. 1996), but not the effects of macroalgal decomposition.
In addition, previous studies on decomposition have largely ignored the effects of macroalgal detritus decomposition on microbenthic community at the microscopic scale.

The aim of our study was to experimentally analyse at a microscale the biogeochemical consequences of decomposition of a macroalgal bloom on shallow sediments. We use here a microcosm approach, where the consequences of bloom decomposition on photosynthetic sediment were evaluated in the bulk water phase (dissolved organic and inorganic carbon, inorganic nutrient) and in the sediment (vertical microprofiles of $\mathrm{O}_{2}, \mathrm{pH}, \mathrm{H}_{2} \mathrm{~S}$ and inorganic nutrients, sediment content of organic matter, inorganic and organic carbon and total nitrogen). The changes in the taxonomic composition of the microphytobenthic community were also studied due to its possible effects on higher trophic levels. The duration of the experiment was long enough to encompass the decomposition of the macroalgal detritus and its subsequent fertilizing effects on the microbenthic community.

\section{MATERIALS AND METHODS}

Microcosm set-up. The sediment (upper $5 \mathrm{~cm}$ layer) and macroalgae were collected from muddy intertidal flats ('Río San Pedro', Cádiz Bay, Spain). The sediment was sieved ( $1 \mathrm{~mm})$ and placed inside an aquarium (46× $28 \times 20 \mathrm{~cm})$, producing a layer 6 to $7 \mathrm{~cm}$ thick. The aquarium was filled with $16 \mathrm{l}$ of seawater collected in situ and filtered $(5 \mu \mathrm{m})$, producing a water column $12 \mathrm{~cm}$ high. This microcosm was maintained on a 12:12 h light:dark photoperiod with continually flowing seawater $\left(1.8 \mathrm{l} \mathrm{h}^{-1}\right.$; hydraulic retention time: $\left.8 \mathrm{~h}\right)$ at $22 \pm 2{ }^{\circ} \mathrm{C}$. During the light period, the aquarium was illuminated at $350 \mu \mathrm{mol}$ photons $\mathrm{m}^{-2} \mathrm{~s}^{-1}$ using six $68 \mathrm{~W}$ fluorescent tubes ( 3 Grolux and 3 white lights). The microbenthic community developed over 20 d before addition of macroalgal detritus at the beginning of the experiment (Fig. 1).

The macroalgae collected included tubular Ulva sp. (formerly Enteromorpha sp., Hayden et al. 2003) and minor amounts of planar Ulva sp., which are common members of spring blooms in the Cádiz Bay. After collection, the macroalgal biomass was rinsed with seawater and killed by freezing at $-80^{\circ} \mathrm{C}$. Macroalgae were thawed immediately before being added to the aquarium. The aquarium was supplied with a total amount of $280 \mathrm{~g} \mathrm{FW}$ of dead macroalgae, equivalent to an input of $220 \mathrm{~g} \mathrm{DW} \mathrm{m}^{-2}$ of macroalgal detritus. This macroalgal cover is typical in the Bay of Cádiz and lower than that reported in more eutrophic coastal areas (Viaroli et al. 2001). Before the addition of macroalgae, the microcosm was sampled to determine 


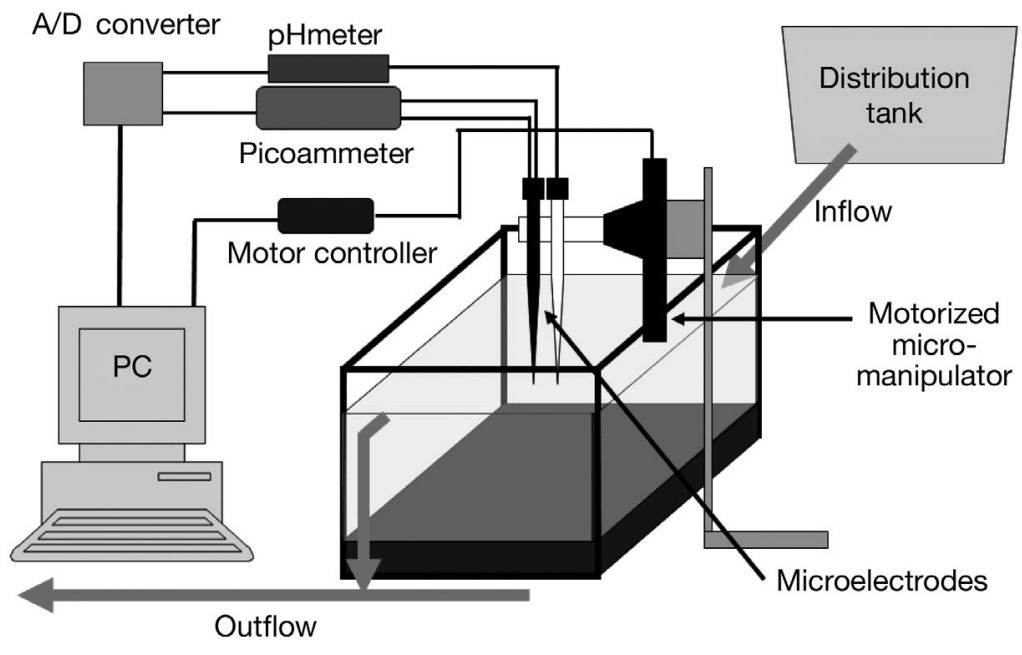

Fig. 1. Mesocosm and microelectrode set-up

$$
J(z)=-D_{\mathrm{o}} \cdot[\partial \mathrm{C}(\mathrm{z}) / \partial \mathrm{z}]
$$

where $D_{\mathrm{o}}$ is the free solution molecular diffusion coefficient of each nutrient and $[\partial \mathrm{C}(\mathrm{z}) / \partial \mathrm{z}]$ is the linear nutrient concentration gradient across the sediment-water interface (up to a depth of 2 to $3 \mathrm{~mm}$ ). $D_{\text {o }}$ was used because we observed a linear gradient across the diffusive boundary layer (DBL) and the upper layer of the sediment, suggesting a very high porosity in the upper layers of the microcosm sediment. Effective DBL was determined from the $\mathrm{O}_{2}$ profiles. $D_{\mathrm{o}}$ values for each nutrient in seawater were taken from Boudreau (1997). Positive and negative fluxes indicated net export of nutrients out of the sediment or net uptake, respectively.

Inorganic nutrient contents of macroalgae were measured after Corzo \& Niell (1992). Macroalgae were dried at $70^{\circ} \mathrm{C}$ for $24 \mathrm{~h}$ and ground to an homogeneous powder. Inorganic nutrients were extracted after incubation for $2 \mathrm{~h}$ of $0.05 \mathrm{~g}$ of dry homogenised macroalgal powder in $4 \mathrm{ml}$ of distilled water at room temperature. Extracts were centrifuged at $4500 \mathrm{rpm}$ for $10 \mathrm{~min}$ and inorganic nutrients were measured in the collected supernatant using a TRAACS-800 analyser.

Organic matter, carbon and nitrogen content of sediment and macroalgae. Organic matter, carbon and nitrogen content were determined in the upper $1 \mathrm{~cm}$ of sediment cores (i.d.: $1.2 \mathrm{~cm}, \mathrm{n}=2$ ). Organic matter was determined by loss on ignition. Total amounts of carbon and nitrogen were analyzed in dried sediment samples using a Leco CHNS $932{ }^{\circledR}$ Analyzer. Inorganic carbon was determined in previously burned $\left(550^{\circ} \mathrm{C}\right)$ samples and the organic fraction was determined as the difference between total and inorganic fractions.

Carbon and nitrogen content of macroalgae were determined in dried $\left(70^{\circ} \mathrm{C}\right.$ for $\left.24 \mathrm{~h}\right)$ and ground samples with a Leco CHNS 932 ${ }^{\circledR}$ Analyzer.

Vertical profiles of $\mathrm{O}_{2}, \mathbf{p H}$ and $\mathbf{H}_{2} \mathrm{~S}$. Vertical profiles of $\mathrm{O}_{2}, \mathrm{pH}$ and $\mathrm{H}_{2} \mathrm{~S}$ at the sediment-water interface were measured with microelectrodes (tip diameter 20 to $30 \mu \mathrm{m}$, Unisense ${ }^{\circledR}$ ) using the experimental set up shown in Fig. 1. The microelectrodes were mounted in pairs in a motor controlled micromanipulator (MC-232, Unisense ${ }^{\circledR}$ ) connected to a PC, and were driven down into the sediment with a step resolution of $100 \mu \mathrm{m}$. The high-sensitivity picoammeter (Unisense PA2000 ${ }^{\circledR}$ ) and the high impedance $\mathrm{mV}$-meter (MeterLab) were connected to a PC using an A/D converter (ACD-101, Unisense $\left.{ }^{\circledR}\right)$. For each sampling day, at least 4 vertical profiles of $\mathrm{O}_{2}, \mathrm{pH}$ and $\mathrm{H}_{2} \mathrm{~S}$ were measured. Steadystate profiles were made using the software Profix using the equation of Fick's first law of diffusion: 
$3.05^{\circledR}$ (Unisense ${ }^{\circledR}$ ). The $\mathrm{O}_{2}$ microelectrode (Revsbech 1989) was calibrated using $100 \%$ saturation of $\mathrm{O}_{2}$ in the air-bubbled bulk water phase of the microcosm, while $0 \%$ saturation was achieved in the anoxic layer inside the sediment. The $\mathrm{pH}$ microelectrode (Revsbech et al. 1983) was calibrated in 3 phosphate buffer solutions $(0.1 \mathrm{M})$ of known $\mathrm{pH}(6,8$ and 10$)$. The sulphide microelectrode was calibrated by adding known volumes of an anoxic $50 \mathrm{mM} \mathrm{Na}_{2} \mathrm{~S}$ stock solution in $0.1 \mathrm{M}$ $\mathrm{NaOH}$ to a $100 \mathrm{mM}$ phosphate buffer at $\mathrm{pH} 7$ in anoxic conditions (Kühl et al. 1998). Oxygen fluxes across the sediment-water interface were calculated from steady state vertical profiles using Eq. (1), where $D_{\mathrm{o}}$ is the free solution molecular diffusion coefficient of $\mathrm{O}_{2}$ and $[\partial \mathrm{C}(\mathrm{z}) / \partial \mathrm{z}]$ is the linear $\mathrm{O}_{2}$ concentration gradient across the DBL. The value of $D_{\text {o }}$ was taken from Li \& Gregory (1974). Additional methodological details can be found elsewhere (Corzo et al. 2005, Garcia de Lomas et al. 2005).

Pigment analysis and taxonomic composition of microbenthos. Sediment cores (i.d.: $1.2 \mathrm{~cm}, \mathrm{n}=6$ ) were taken and frozen immediately at $-80^{\circ} \mathrm{C}$. Each core was sliced in thin sections (ca. $1 \mathrm{~mm}$ ), which were pooled by depth, homogenised and sonicated (30 s at $15 \mathrm{~W})$. Phycobiliproteins were extracted in $2 \mathrm{ml}$ phosphate buffer $(0.2 \mathrm{M}, \mathrm{pH}=6.5)$ and left overnight at $4^{\circ} \mathrm{C}$ in darkness (Thinh 1983). Chlorophyll a was extracted in
$2 \mathrm{ml} \mathrm{100 \%} \mathrm{methanol} \mathrm{(Thompson} \mathrm{et} \mathrm{al.} \mathrm{1999)} \mathrm{and} \mathrm{left}$ overnight at $4^{\circ} \mathrm{C}$ in darkness. Extracts were centrifuged at $4500 \mathrm{rpm}$ for $10 \mathrm{~min}$ and the absorption spectrum between 400 and $800 \mathrm{~nm}$ was obtained using a spectrophotometer (Unicam UV/VIS UV2 ${ }^{\circledR}$ ). Phycobiliproteins (phycoerythrin and phycocyanin) were estimated after Bennet and Bogorad (1973), while chl a was estimated after Pierson et al. (1987).

For taxonomic composition and abundance of microphytobenthos, the upper $5 \mathrm{~mm}$ of sediment cores $(\mathrm{n}=$ 2) were taken and fixed with glutaraldehyde $(2.25 \%$ in $5 \mu \mathrm{m}$ filtered seawater). Abundances of Cyanobacteria and diatoms were determined by light microscopy in $50 \mu$ l of a diluted (50x) and homogenised sediment suspension by counting a minimum number of 400 cells along random transects in the microscopic fields. Taxonomic identifications of microalgae were made according to Bourrelly $(1970,1981)$ and Boone \& Castenholz (2001).

Statistical analysis. Differences over time or between depths for the measured variables were tested by 1-way and 2-way analyses of variance (ANOVA) followed by the least significant difference (LSD) method for multiple pairwise comparisons. Two means comparisons were done with the $t$-test method. Statistical analyses were performed using the software Statgraphics Plus 5.1.
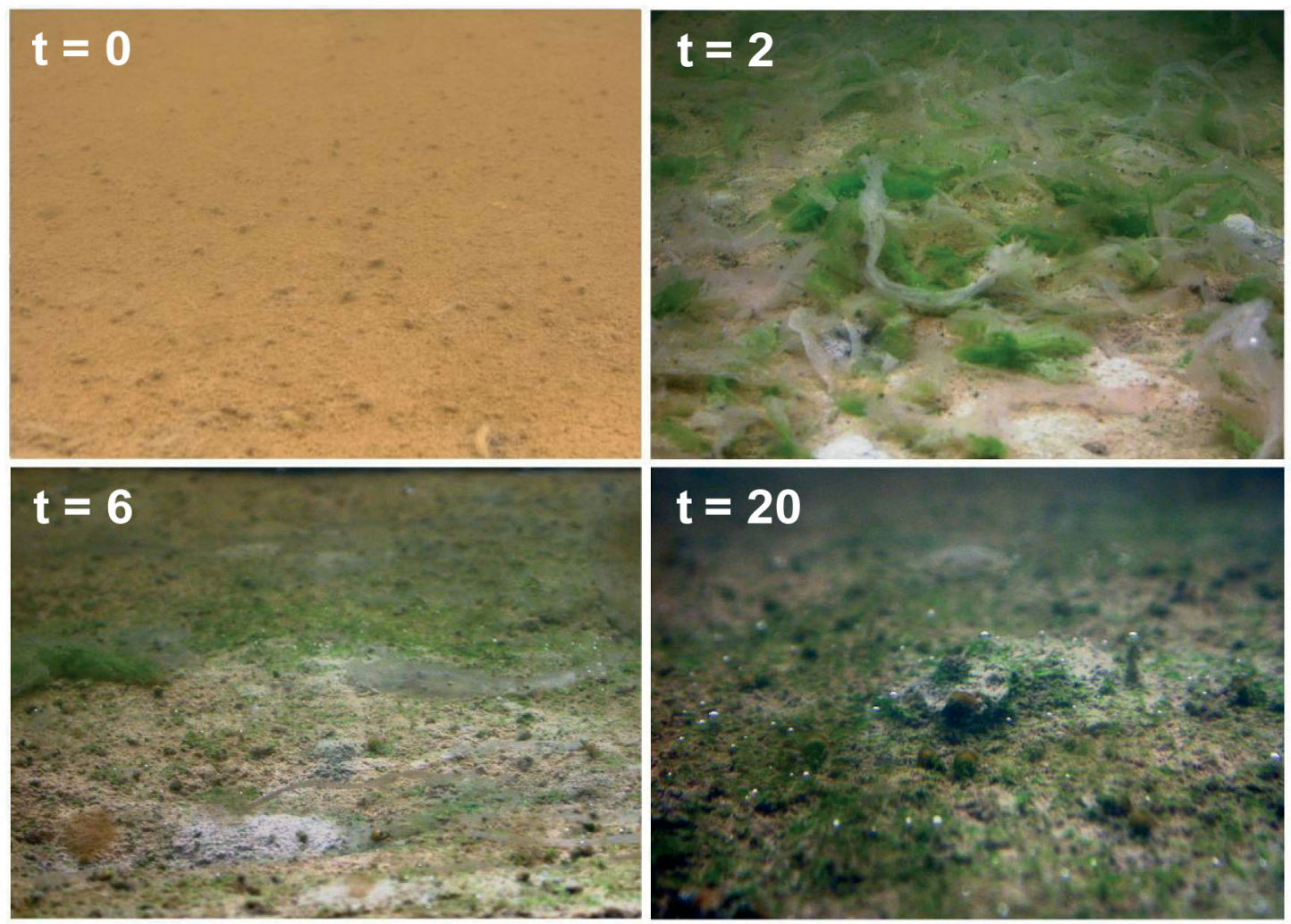

Fig. 2. Changes in the macroscopic appearance of the sediment surface in the mesocosm over $20 \mathrm{~d}(t=1$ to 20$)$. Macroalgal detritus was added at Day $t=0$ after measurements of initial conditions 


\section{RESULTS}

\section{Macroscopic description}

The sediment was muddy and the surface appeared oxidised, showing a light brown colour at the initial stage $\left(t_{0}\right)$. Dead macroalgae began to whiten and settled during the first $2 \mathrm{~d}$ following addition. They formed a heterogeneous layer of detritic organic matter in the sediment surface leaving patches of uncovered sediment (Fig. 2). After $6 \mathrm{~d}$, almost all of the macroalgal detritus had disappeared, and only a few small fragments remained on the sediment surface. The mineralization of macroalgal detritus appeared to stimulate the microphytobenthic community, producing a green compact biofilm on the surface of the sediment as macroalgal detritus disappeared.

\section{Transfer of organic matter to the water column and sediment}

Decomposition of macroalgal detritus released DOC to the water column as indicated by the rapid increase to more positive values in the microcosm balance for DOC after the addition of dead macroalgae (Fig. 3A). This increase was also associated with a transient shift in the microcosm balance for inorganic carbon from net negative to net positive during the first stage of decomposition (Fig. 3A).

The organic matter content of the sediment increased from $111.47 \pm 19.25$ to $206.53 \pm 52.47 \mathrm{mg}$ $\mathrm{g}^{-1} \mathrm{DW}$ (mean $\pm \mathrm{SD}, \mathrm{p}<0.01, t$-test) during the first $3 \mathrm{~d}$ after addition of macroalgal detritus. However, the increase in OM was transitory, decreasing steadily from the 3rd day down to initial values (Fig. 3B). Organic carbon content $\left(\mathrm{C}_{\text {org }}\right)$ increased significantly during the first $6 \mathrm{~d}$ after addition of dead macroalgae (from $1.74 \pm 0.01$ to $2.01 \pm$ 0.13 mmol $\mathrm{C} \mathrm{g} \mathrm{g}^{-1} \mathrm{DW}$; mean $\pm \mathrm{SD}, \mathrm{p}<0.01, t$-test), then decreased steadily to the end of the experiment (Fig. 3C). Total nitrogen content of sediment (N) increased significantly after addition of macroalgal detritus $\left(0.12 \pm 0.01\right.$ to $0.16 \pm 0.02 \mathrm{mmol} \mathrm{N} \mathrm{g}^{-1}$ DW at Day 6 ; mean \pm SD, p $<0.01, t$-test), then decreased towards the end of the experiment (Fig. 3C). The sediment $\mathrm{C}: \mathrm{N}$ ratio (as $\mathrm{C}_{\text {org }} / \mathrm{N}$ ) increased significantly from $15.78 \pm 2.41$ before the addition of dead macroalgae to $19.78 \pm 1.99$ after $3 \mathrm{~d}$ (mean $\pm \mathrm{SD}, \mathrm{p}<0.05, t$-test) decreasing to the initial value later (Fig. 3B). Inorganic carbon content of sediment $\left(\mathrm{C}_{\text {inorg }}\right)$ showed a transient but significant decrease from $1.08 \pm 0.05$ to $0.88 \pm 0.06 \mathrm{mmol}$ $\mathrm{C}^{-1}$ DW in the 1st day after addition of macroalgae (mean $\pm \mathrm{SD}, \mathrm{p}<0.01, t$-test)
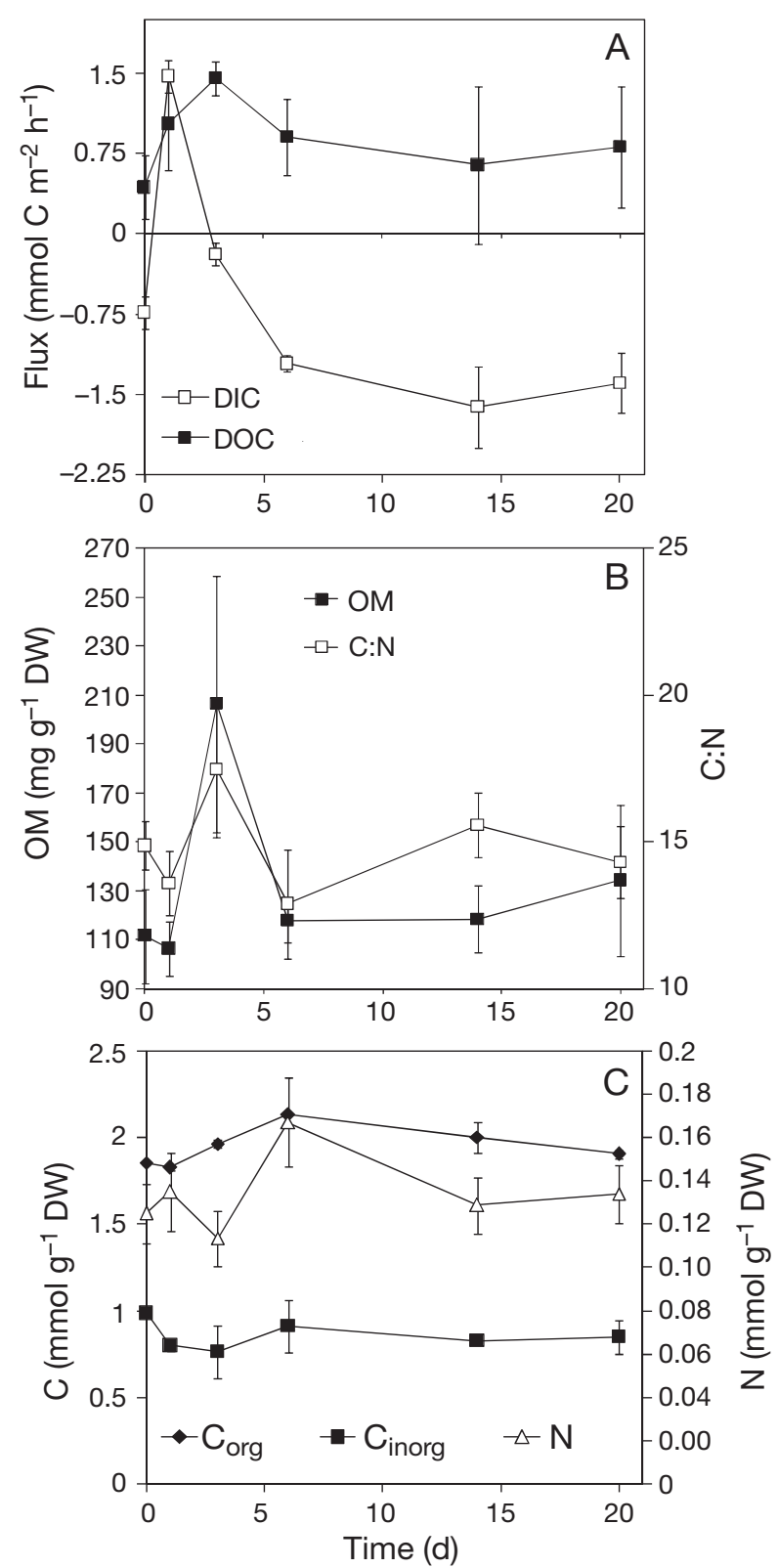

Fig. 3. (A) Microcosm mass balance (outflow-inflow) for dissolved inorganic carbon (DIC) and dissolved organic carbon (DOC) $(\mathrm{n}=2)$. (B) Changes in organic matter $(\mathrm{OM})$ content $(n=2)$ and the organic carbon:total nitrogen ratio $(C: N)$ of microcosm sediment $(n=4)$. $(C)$ Total nitrogen $(N)$, organic carbon $\left(\mathrm{C}_{\text {org }}\right)$ and inorganic carbon $\left(\mathrm{C}_{\text {inorg }}\right)$ content of microcosm sediment $(n=4)$. Values are means $\pm S D$

\section{Concentration and fluxes of inorganic nutrient}

The microcosm received an important input of intracellular inorganic nutrient with the addition of macroalgal detritus (Table 1). $\mathrm{NH}_{4}{ }^{+}$represented $96.5 \%$ of the intracellular inorganic nitrogen. Vertical profiles of inorganic nutrients before the addition of macroalgal detritus showed the existence of a deep layer at about 
Table 1. Mean concentration $\pm \mathrm{SD}(\mathrm{n}=2)$ of inorganic nutrients in the macroalgal detritus added to the microcosm, mean inorganic nutrient concentration $\pm \mathrm{SD}$ in the inflow seawater $(\mathrm{n}=6)$ and microcosm mass balance for the entire experiment taking into account the water flow velocity and the duration of the experiment $(20 \mathrm{~d})$. Inflow and outflow are total input and output, respectively, of nutrient in inflowing and outflowing seawater for $20 \mathrm{~d}$

\begin{tabular}{|lccrrrrr|}
\hline Nutrient & $\begin{array}{c}\text { Macroalgae } \\
\left(\mu \mathrm{mol} \mathrm{g}{ }^{-1} \mathrm{DW}\right)\end{array}$ & $\begin{array}{c}\text { Inflow } \\
\text { seawater } \\
\left(\mu \mathrm{mol} \mathrm{l^{-1 }}\right)\end{array}$ & $\begin{array}{c}\text { Macroalgae } \\
(\mu \mathrm{mol})\end{array}$ & $\begin{array}{c}\text { Inflow } \\
(\mu \mathrm{mol})\end{array}$ & $\begin{array}{c}\text { Outflow } \\
(\mu \mathrm{mol})\end{array}$ & $\begin{array}{c}\text { Balance } \\
\text { outflow-inflow } \\
(\mu \mathrm{mol})\end{array}$ & $\begin{array}{c}\text { Balance outflow- } \\
\text { macroalgae } \\
+ \text { inflow })(\mu \mathrm{mol})\end{array}$ \\
\hline $\mathrm{NH}_{4}{ }^{+}$ & $53.5 \pm 4.7$ & $1.9 \pm 0.6$ & 1132.93 & 1751.29 & 2809.78 & 1058.50 & -74.44 \\
$\mathrm{NO}_{3}{ }^{-}$ & $1.7 \pm 1.0$ & $1.5 \pm 0.9$ & 36.65 & 989.58 & 1598.18 & 608.60 & 571.95 \\
$\mathrm{NO}_{2}{ }^{-}$ & $0.2 \pm 0.0$ & $0.5 \pm 0.5$ & 3.98 & 328.05 & 245.77 & -82.28 & -86.26 \\
$\mathrm{PO}_{4}^{-}$ & $11.7 \pm 02$ & $0.6 \pm 0.2$ & 247.40 & 483.08 & 523.30 & 40.22 & -207.18 \\
$\mathrm{SiO}_{3}{ }^{2-}$ & $1.6 \pm 0.7$ & $11.4 \pm 0.3$ & 35.05 & 9851.74 & 13074.60 & 3222.86 & 3187.80 \\
\hline
\end{tabular}

2.5 to $4.5 \mathrm{~mm}$ below the sediment surface with maximum concentrations of $\mathrm{NH}_{4}{ }^{+}, \mathrm{NO}_{3}{ }^{-}, \mathrm{NO}_{2}{ }^{-}, \mathrm{PO}_{4}{ }^{3-}$ and $\mathrm{SiO}_{3}{ }^{2-}$ (Fig. 4). The deposition of macroalgae on the sediment induced a migration of the subsurface maxi-
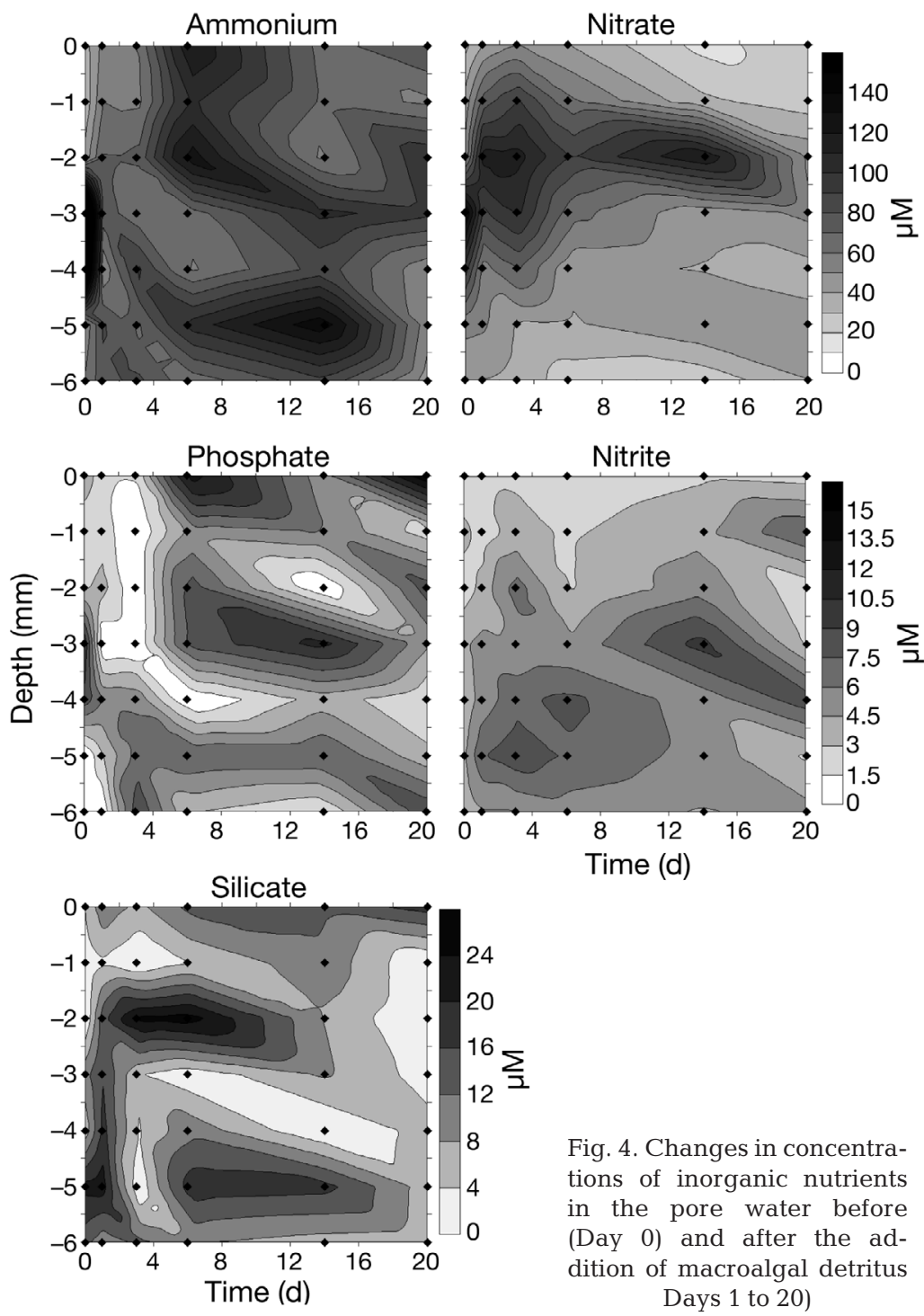

Fig. 4. Changes in concentrations of inorganic nutrients in the pore water before (Day 0) and after the addition of macroalgal detritus Days 1 to 20) mum of $\mathrm{NO}_{3}{ }^{-}$and $\mathrm{SiO}_{3}{ }^{2-}$ towards to the sediment surface. However, this pattern was not observed as clearly for $\mathrm{NH}_{4}{ }^{+}, \mathrm{NO}_{2}{ }^{-}$and $\mathrm{PO}_{4}{ }^{3-}$. Maximum $\mathrm{NH}_{4}{ }^{+}$concentrations at the sediment surface were observed on Day 6 and were coincident with a high $\mathrm{PO}_{4}{ }^{3-}$ concentration.

Concentrations of inorganic nutrients in the bulk water were lower than those measured in sediment except for $\mathrm{SiO}_{3}{ }^{2-}$ (Fig. 5). Net fluxes (calculated from the concentration gradient at the sediment-water interface) showed a rapid, transient increase in the net efflux of $\mathrm{NO}_{3}{ }^{-}$, which peaked at Days 1 and 3 and slowly decreased through to the end of the experiment. $\mathrm{NH}_{4}{ }^{+}$net efflux rate increased after the addition of macroalgal detritus, peaked at Day 14 and remained high up to end of the experiment. $\mathrm{NO}_{2}{ }^{-}$and $\mathrm{PO}_{4}{ }^{3-}$ net effluxes were lower than those of $\mathrm{NO}_{3}{ }^{-}$and $\mathrm{NH}_{4}{ }^{+}$throughout the experiment.

The net balance of inorganic nutrients for the microcosm calculated from Eq. (1) indicated that in the initial conditions all nutrients except $\mathrm{NH}_{4}{ }^{+}$were being consumed within the system. After the addition of macroalgae, the microcosm shifted quickly from being a net sink to a net exporter of $\mathrm{NO}_{3}{ }^{-}, \mathrm{NO}_{2}{ }^{-}, \mathrm{PO}_{4}{ }^{3-}$ and $\mathrm{SiO}_{3}{ }^{2-}$. At Days 14 and 20, the system seemed to be slowly returning to the initial conditions except for $\mathrm{SiO}_{3}{ }^{2-}$ (Fig. 5B). The total balance for $20 \mathrm{~d}$ indicated that the microcosm consumed $\mathrm{NH}_{4}{ }^{+}, \mathrm{NO}_{2}{ }^{-}$and $\mathrm{PO}_{4}{ }^{3-}$ and released $\mathrm{NO}_{3}{ }^{-}$ and $\mathrm{SiO}_{3}{ }^{2-}$ (Table 1).

\section{Changes in net metabolism}

Oxygen concentration in the water column and within the sediment decreased quickly after the addition of macroalgal 

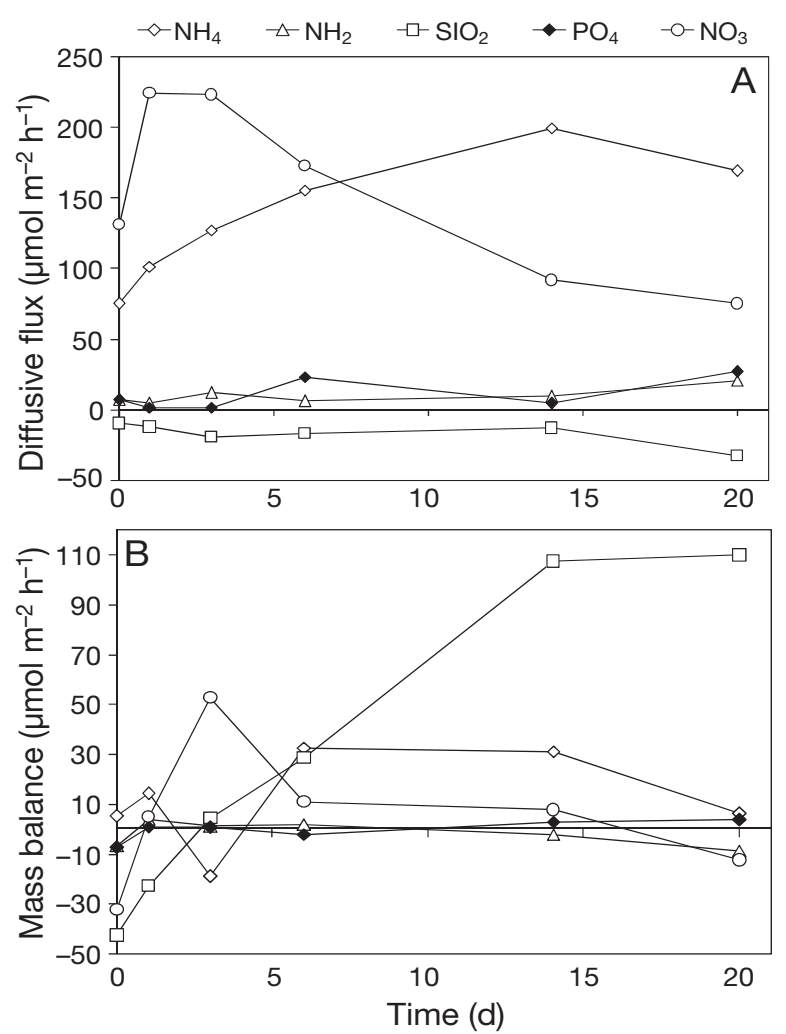

Fig. 5. (A) Fluxes of inorganic nutrients at the sedimentwater interface calculated from nutrient concentration profiles in the sediment and the nutrient concentration in the bulk water phase of the microcosm. (B) Whole microcosm balance for inorganic nutrients. Positive and negative values indicate net release and net uptake, respectively, from the sediment (A) and/or the microcosm (B)

detritus. Initial oxygen concentration in the bulk water column was $215 \mu \mathrm{mol} \mathrm{O} \mathrm{l}^{-1}$, decreasing to $150 \mu \mathrm{mol} \mathrm{O}$ $\mathrm{l}^{-1}$ and $130 \mu \mathrm{mol} \mathrm{O} \mathrm{O}_{2} \mathrm{l}^{-1}$ in light and darkness, respectively, on the 3rd day (Fig. 6). Decomposition of macroalgal detritus clearly affected the oxygen concentration at the sediment-water interface. The layer
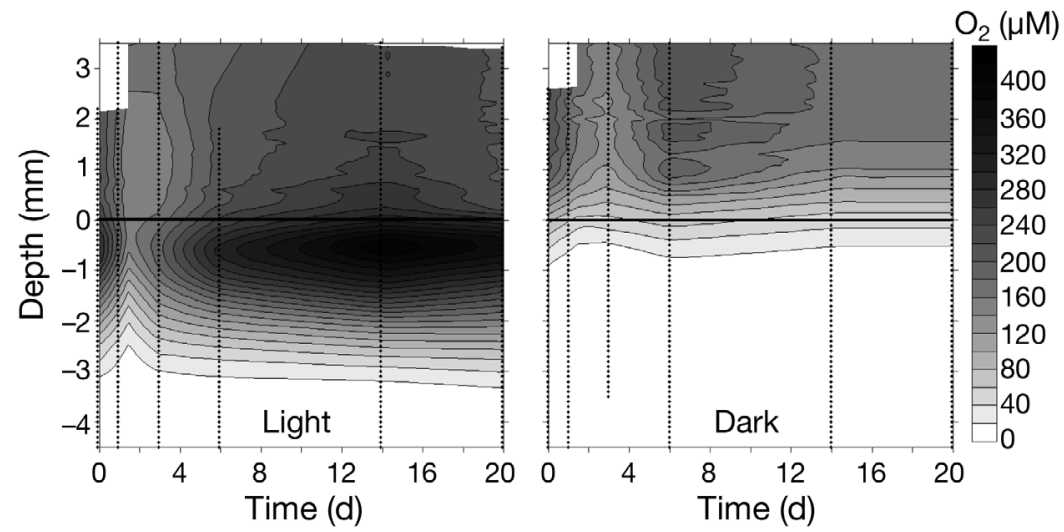

Fig. 6. Oxygen concentration in the sediment-water interface measured before (Day 0) and after addition of macroalgal detritus (Days 1 to 20) in the light and in the dark. Plotted dates of every sampling day are means of 4 to 5 $\mathrm{O}_{2}$ profiles of macroalgal detritus over the sediment transiently suppressed photosynthetic activity of microphytobenthos at the beginning of the experiment. Photosynthetic activity was fully recovered from Day 6. Oxygen penetration depth in the sediment decreased transiently after addition of macroalgal detritus, reaching minimum values on Day 3 (Fig. 6).

Oxygen fluxes between the sediment and the water column (calculated from $\mathrm{O}_{2}$ microprofiles) decreased slightly (both in the light and in the dark) when the macroalgal detritus covered the sediment at the beginning of the experiment (Fig. 7A). However the differences were not significant, likely due to the heterogeneous cover of macroalgal detritus (see below). Net photosynthetic production and dark respiration started to recover from Day 3, reaching maximum values at the end of the experiment. On a daily basis, taking into account the net photosynthesis and dark respiration rates and the corresponding duration of the light and dark periods (daily net primary production), the sediment in the microcosm was net heterotrophic before the addition of macroalgal detritus but became net autotrophic towards the end of the experiment.

The sedimentation of macroalgal detritus created a considerable spatial heterogeneity in the sediment surface because it was not covered uniformly. During the first 3 to $4 \mathrm{~d}$, covered and uncovered areas were clearly distinguishable (Fig. 2, $t=2$ ). To account for the spatial heterogeneity of the cover of dead macroalgae detritus on the sediment surface, we measured $\mathrm{O}_{2}$ profiles and the corresponding fluxes in covered and uncovered areas during the first $3 \mathrm{~d}$ (Fig. 7B,C). Net production rates in covered areas decreased significantly $(\mathrm{p}<$ $0.05, t$-test) from rates of $0.42 \pm 0.86 \mathrm{mmol} \mathrm{O}_{2} \mathrm{~m}^{-2} \mathrm{~h}^{-1}$ to values of $-0.62 \pm 0.63 \mathrm{mmol} \mathrm{O}_{2} \mathrm{~m}^{-2} \mathrm{~h}^{-1}$ on the 3rd day. In contrast, net production rate increased slightly (but not significantly in areas without macroalgae cover) up to $0.87 \pm 0.32 \mathrm{mmol} \mathrm{O}_{2} \mathrm{~m}^{-2} \mathrm{~h}^{-1}$. Similarly, dark respiration rates decreased significantly in covered areas from values of $-0.93 \pm$ $0.12 \mathrm{mmol}$ to $-0.36 \pm 0.22 \mathrm{O}_{2} \mathrm{~m}^{-2} \mathrm{~h}^{-1}$ on the 3rd day ( $\mathrm{p}<0.01, t$-test). No significant differences were observed in dark respiration rates during the first $4 \mathrm{~d}$ in uncovered areas.

\section{pH profiles and $\mathrm{H}_{2} \mathrm{~S}$}

Vertical profiles of $\mathrm{pH}$ at the sediment-water interface were closely dependent on photosynthetic activity of the microphytobenthic community, and therefore differed in the light and dark periods (Fig. 8). Initially, the mineraliza- 

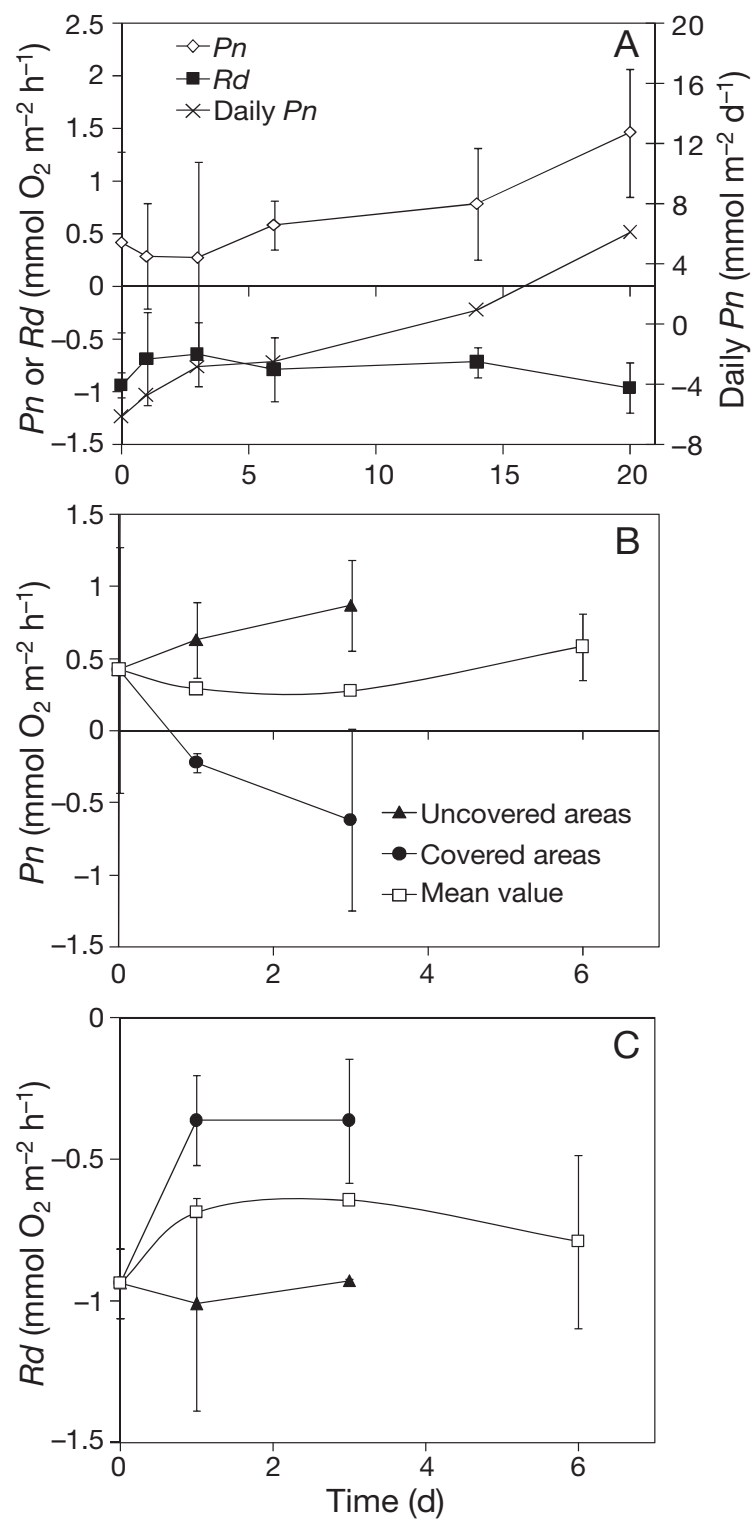

Fig. 7. Oxygen fluxes across the sediment surface. (A) Net production rates $(P n)$, respiration rates $(R d)$ and daily net production rates (Daily $P n$ ). Plotted data are means of 4 or 5 profiles. (B) Spatial heterogeneity in net production rates due to presence (covered areas) and absence (uncovered areas) of macroalgal detritus during the first $3 \mathrm{~d}$. Mean rates are presented for comparison. (C) Spatial heterogeneity in dark respiration rates due to presence (covered areas) and absence (uncovered areas) of macroalgal detritus during the first $3 \mathrm{~d}$. $R d$ values are negative for clarity. Plotted data are means of 2 or 3 profiles. Error bars represent SDs

tion of macroalgal detritus decreased the $\mathrm{pH}$ in light and darkness. This decrease was observed both in the water column and within the sediment. However after the 3rd day, the microphytobenthic photosynthetic activity produced a progressively greater difference in $\mathrm{pH}$ between the daily periods of light and dark. Daily
$\mathrm{pH}$ oscillations of 1 to 2 units between the light and dark periods occurred in the water column and in the sediment (500 $\mu \mathrm{m}$ depth) at the end of the experiment (Fig. $8 \mathrm{C}, \mathrm{D}$ ). $\mathrm{H}_{2} \mathrm{~S}$ concentration in the upper $6 \mathrm{~mm}$ of sediment was frequently unmeasurable in the dark and very low in the light before and after the addition of macroalgal detritus (results not shown). At this low concentration, the known sensitivity of the $\mathrm{H}_{2} \mathrm{~S}$ microsensor to light produced erratic and unrealistic profiles for the water column and the sediment photic layer.

\section{Microphytobenthic community}

Chl a concentration decreased to minimum values at Day 3 (Fig. 9A). After Day 3, Chl a increased significantly and remained higher than at $t_{0}$ up to the end of the experiment. The sediment content of phycobiliprotein (PBP) was minimum on Day 3 and increased considerably from this day up to the end of the experiment, as did Chl a. However the PBP:Chl a ratio increased from 0.03 at $t_{0}$ to 0.06 at the end of the experiment, suggesting a stronger dominance of cyanobacteria in the photoautotrophic microbial community.

The taxonomic composition of the microphytobenthic community changed after the addition of macroalgal detritus (Table 2). Abundance of Cyanobacteria at $t_{0}(57 \%)$ increased further to $66 \%$, while the abundance of diatom decreased from 43 to $34 \%$ at the end of the experiment. Leptolyngbya sp., Merismopedia sp. and Johannesbaptistia sp. dominated the cyanobacterial community throughout the experiment, although the abundance of Merismopedia sp. and particularly Johannesbaptistia sp. increased towards the end of the experiment. Abundant diatoms were Nitzschia sp., Gyrosigma sp., Navicula sp. and Cylindrotheca sp.

\section{DISCUSSION}

\section{Experimental limitations}

The study of decomposition requires killing macroalgae, ideally without affecting their tissular structure and degradability. As far as we know, killing by freezing is the only procedure that has been assessed so far (Buchsbaum et al. 1991, Nedergaard et al. 2002, Castaldelli et al. 2003). However no information is available on how the freeze-thaw treatment might affect the tissue structure of macroalgae and how it could affect the initial phase of the decomposition process, for instance by facilitating the release of dissolved 

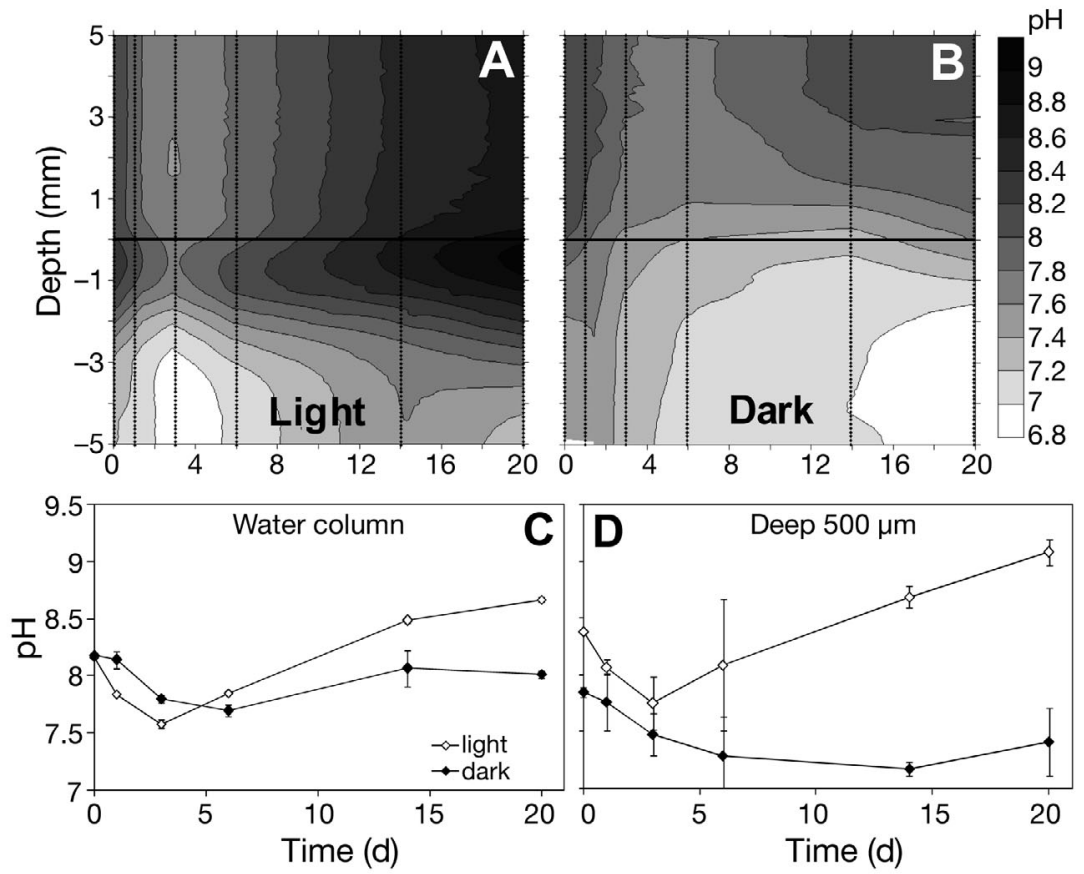

Fig. 8. pH changes at the sediment-water interface (A) in light and (B) in the dark. Plotted data are means of 2 to 4 profiles. (C) $\mathrm{pH}$ changes in the bulk water in the light and in the dark. (D) $\mathrm{pH}$ changes within the sediment (at a depth of $500 \mu \mathrm{m}$ ) in the light and in the dark. Error bars represent SDs

effect of macrofauna and tidal movements and associated currents that might play a role in the decomposition of macroalgae have not been considered in our experimental design.

\section{Decomposition of macroalgae and transfer of organic matter to the water column and sediment}

The decomposition of macroalgal detritus involves the rapid leaching of soluble materials in a cellular autolytic process that is independent of microbial activity. During a second phase, microbial exoenzymes continue the decomposition of labile macromolecules, leading to further release of low molecular weight DOC (Valiela et al. 1985, Castaldelli et al. 2003). These 2 phases lasted less than $1 \mathrm{wk}$, similar to previous observations (Astill \& Lavery 2001, Castaldelli et al. 2003). We detected the transfer of the detrital $\mathrm{C}$ from macroalgae to the water column as DOC during the 1st day

compounds. Likely, due to this uncertainty, some studies on decomposition chose to start with live macroalgae, inducing their senescence in the dark (Williams 1984, Lomstein et al. 2006). However, this leads to an even more complex situation where the macroalgal biomass is partially alive and partially decomposing, and this precludes the study of decomposition processes in the light. In addition, laboratory experiments have demonstrated that Ulva spp. and other macroalgae can survive for very long periods in the dark (Gabrielson et al. 1983, Kamermans et al. 1998). The microcosm set up can not capture the whole in situ complexity of the decomposition process. The after the addition of macroalgal detritus, although maximum net rates were observed at Day 3 (Fig. 3A). The deposition of macroalgal detritus on the sediment surface represented an important input of $\mathrm{C}_{\text {org }}$ for the sediment as well (Fig. 3B). Once the macroalgal detritus settled on the sediment, a fraction of the released DOC was likely transferred to the sediment pore water. These organic compounds were relatively depleted in $\mathrm{N}$ since the $\mathrm{C}: \mathrm{N}$ ratio increased during the initial stage of decomposition. Increases in the C:N ratios of mineralization products have also been observed in mats of senescent-decomposing macroalgae (Lomstein et al. 2006).
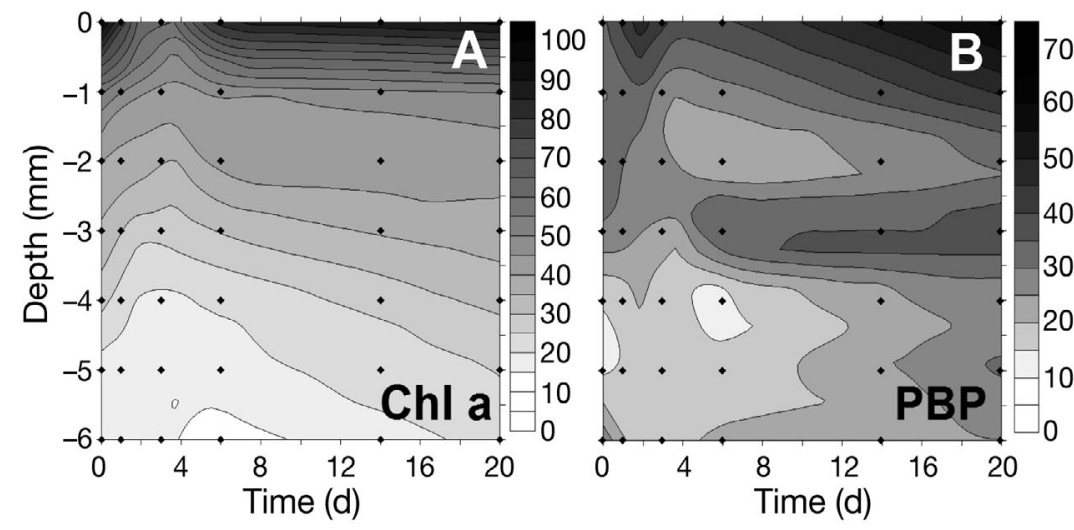

Fig. 9. Vertical profiles of (A) chl a and (B) phycobiliproteins (phycoeryrthrin and phycocyanin)

\section{Nutrient remineralization}

The addition of macroalgal detritus shifted the microcosm balance for all measured nutrients to net production (Fig. 5). Initially, $\mathrm{NO}_{3}^{-}$and $\mathrm{NH}_{4}{ }^{+}$may have been released from intracellular pools since green macroalgae accumulate these nutrients in large concentrations (Corzo \& Niell 1992). However, the total amounts of intracellular $\mathrm{NO}_{3}{ }^{-}$and $\mathrm{NH}_{4}{ }^{+}$introduced with macroalgal detritus were 37 and $1133 \mu \mathrm{mol}$ respectively (Table 1). This relatively small amount of 
Table 2. Changes in taxonomic composition of the microphytobenthic community. Values are means $\pm \mathrm{SD}(\mathrm{n}=2)$ before $\left(t_{0}\right)$ and $20 \mathrm{~d}$ after addition of macroalgae $\left(t_{20}\right)$. Values in brackets are percentages of the whole community

\begin{tabular}{|lcc|}
\hline \multicolumn{2}{c|}{$t_{0}$} & $t_{20}$ \\
\hline Cyanobacteria $\left(\times 10^{5}\right) \mathrm{ml}^{-1}(\%)$ \\
Leptolyngbya sp. & $4.80 \pm 0.93(55.60)$ & $2.88 \pm 0.62(43.06)$ \\
Merismopedia sp. & $0.07 \pm 0.02(0.83)$ & $0.10 \pm 0.09(1.56)$ \\
Johannesbaptistia sp. & $0.05 \pm 0.01(0.58)$ & $0.71 \pm 1.00(21.25)$ \\
Spirulina sp. & $0.01 \pm 0.02(0.13)$ & 0 \\
TOTAL & $4.93 \pm 0.96(57.14)$ & $3.69 \pm 1.53(65.86)$ \\
Diatoms & & 0 \\
Nitzschia sp. & $0.54 \pm 0.76(6.25)$ & $0.27 \pm 0.11(3.97)$ \\
Gyrosigma sp. & $0.83 \pm 0.13(9.58)$ & 0 \\
Navicula sp. & $0.40 \pm 0.23(4.68)$ & $0.35 \pm 0.09(5.24)$ \\
Cylindrotheca sp. & $0.20 \pm 0.04(2.33)$ & $0.28 \pm 0.00(4.25)$ \\
Entomoneis sp. & $0.18 \pm 0.03(2.02)$ & $1.40 \pm 0.03(23.45)$ \\
Unidentified & $1.06 \pm 0.94(12.24)$ & $2.28 \pm 0.07(34.14)$ \\
TOTAL & $3.70 \pm 1.19(42.86)$ & $5.97 \pm 1.46$ \\
TOTAL & $8.64 \pm 0.23$ & \\
\hline
\end{tabular}

$\mathrm{NO}_{3}{ }^{-}$can explain the change in the microcosm's balance during only the 1st day, but not the extra $\mathrm{NO}_{3}^{-}$ efflux up to Day 3. In addition, we observed only a small $\mathrm{NH}_{4}{ }^{+}$efflux, which peaked at the final stage of decomposition (Day 6). Therefore, intracellular $\mathrm{NH}_{4}^{+}$ released during the initial phase of decomposition must have been partially transformed to $\mathrm{NO}_{2}^{-}$and $\mathrm{NO}_{3}{ }^{-}$by nitrification, or consumed by benthic microalgae and/or heterotrophic bacteria. This $\mathrm{NH}_{4}{ }^{+}$input likely reduced the competition between heterotrophic bacteria and nitrifiers, thus producing an increase in nitrification rates (Strauss \& Lamberti 2000, RisgaardPetersen 2003). The increase in $\mathrm{NO}_{3}{ }^{-}$production rate and the reduction of its consumption rate by microphytobenthos produced a transient increase in $\mathrm{NO}_{3}{ }^{-}$concentration in the porewater that induced a transient efflux to the water column. The initial nitrate efflux may also be caused by a displacement of the nitrification zone upward in the sediment following the decrease in oxygen penetration depth (Fig. 4). A clear increase in the $\mathrm{NH}_{4}{ }^{+}$content of sediment was only observed at Day 6, and it was likely due to ammonification activity on macroalgal organic nitrogen (Fig. 4). During this phase and later, the microphytobenthic community had recovered photosynthetic activity and was growing (Figs. 6, $7 \&$ 9). Assimilation of $\mathrm{NH}_{4}{ }^{+}$by microphytobenthos has been suggested to control the $\mathrm{NH}_{4}{ }^{+}$efflux from the sediment, and likely plays a role in the net flux of $\mathrm{NO}_{3}{ }^{-}$as well (Sundbäck \& Snoeijs 1991, Dalsgaard 2003). Calculated $\mathrm{NO}_{3}{ }^{-}$and $\mathrm{NH}_{4}{ }^{+}$ fluxes at the sediment-water interface were in general higher than those obtained from the microcosm balance, but followed the same general trends (Fig. 5), and were within the range of published values (Risgaard-Petersen 2003, Sundbäck et al. 2004, Eyre \& Ferguson 2005). Disparities between calculated and measured diffusive fluxes are frequently observed, and likely stem from biological processes and methodological procedures. Net fluxes of $\mathrm{PO}_{4}{ }^{3-}$ and $\mathrm{NO}_{2}{ }^{-}$were much lower than those of $\mathrm{NO}_{3}{ }^{-}$and $\mathrm{NH}_{4}{ }^{+}$. This was true even when the intracellular $\mathrm{PO}_{4}{ }^{3-}$ input with macroalgal detritus was relatively high (247 $\mu \mathrm{mol})$ compared with the intracellular $\mathrm{NO}_{2}^{-}$input $(4 \mu \mathrm{mol})$. This suggests a strong $\mathrm{PO}_{4}{ }^{3-}$ consumption rate during the initial decomposition phase since we detected high $\mathrm{PO}_{4}{ }^{3-}$ concentrations within the sediment only after Day 6 (Fig. 4). The bacterial community was likely the major consumer of $\mathrm{PO}_{4}{ }^{3-}$ during the first $3 \mathrm{~d}$ because photosynthetic activity and growth by benthic microalgae were inhibited (Figs. 6, $7 \&$ 9). Our results are contradictory for $\mathrm{SiO}_{3}{ }^{2-}$. According to the total microcosm balance, $\mathrm{SiO}_{3}{ }^{2-}$ was exported from the microcosm after Day 3, while the calculated fluxes across the sediment-water interface and the shape of the vertical profiles within the sediment suggest that there was a net flux from the water to the sediment throughout the experiment. Calculated fluxes across the sediment-water interface are based in a number of assumptions (Boudreau 1997) that might not have been fulfilled for $\mathrm{SiO}_{3}{ }^{2-}$, although they worked reasonably well for other nutrients in same experiment. Clearly the microcosm was a large net source of $\mathrm{SiO}_{3}{ }^{2-}$ (more than $3 \mathrm{mmol}$ over $20 \mathrm{~d}$, Table 1). This $\mathrm{SiO}_{3}{ }^{2-}$ must have originated from within the sediment through a process triggered by macroalgal decomposition.

\section{Effect of macroalgal detritus on the microbenthos net metabolism}

Since $R d$ was higher than $P n$ (Fig. 7B,C), sediment metabolism before the addition of macroalgal detritus was net heterotrophic, according the benthic trophic state index (BTSI) proposed by Rizzo et al. (1996). The sedimentation of macroalgal detritus likely reduced incident light at the sediment surface, as has been shown for live macroalgal mats (Astill \& Lavery 2001). However, the patchy cover of macroalgal detritus produced large horizontal variation in the light reaching the sediment surface. Photosynthetic $\mathrm{O}_{2}$ production was almost completely suppressed in covered patches 
and increased in the uncovered areas (Fig. 7B). Uncovered patches had net $\mathrm{O}_{2}$ production rates double those within the covered areas. This, increase is likely the consequence of the fertilization produced by the rapid release of the inorganic nutrient during the mineralization of macroalgal detritus in nearby covered patches. In the covered patches, light was insufficient to sustain photosynthetic activity and the metabolism of the microbenthic community shifted to fully heterotrophic (according to BTSI). However this inhibition was transient. Photosynthetic $\mathrm{O}_{2}$ production in light began to recover after $3 \mathrm{~d}$ as macroalgal detritus progressively disintegrated, shifting net metabolism of microbenthic community once more from net heterotrophic (Day 6) to net autotrophic (Days 14 and 20).

$\mathrm{O}_{2}$ availability for the sediment was decreased by the presence of the macroalgal detritus because: (1) it represented a physical barrier for mass transfer between the sediment and the bulk water phase, and (2) $\mathrm{O}_{2}$ was being consumed within the macroalgal detritus layer (Pedersen et al. 1999, Nedergaard et al. 2002). This likely explains the decrease of the aerobic respiration rates in covered patches while it remained similar to initial values in uncovered patches (Fig. 7C).

\section{Aerobic/anaerobic mineralization of macroalgal detritus}

The transient accumulation of $\mathrm{C}_{\text {org }}$ and the hypoxicanoxic conditions should have favoured sulfate reduction activity. High levels of sulfate reduction activity have been measured in thalli of decomposing Ulva lactuca in anoxic conditions (Nedergaard et al. 2002) and in sediments below senescent mats of microcosms (Lomstein et al. 2006). However, we did not detect a significant increase in the $\mathrm{H}_{2} \mathrm{~S}$ after the addition of macroalgal detritus. This could be partially due to the relatively low load of macroalgal detritus added in our experiment compared to previous studies. In addition, $\mathrm{H}_{2} \mathrm{~S}$ concentration can be buffered at very low levels in sediments with high Fe content even when rates of sulfate reduction activity are high (Canfield et al. 1992, Kasten \& Jørgensen 2000) like those of Cádiz Bay (12 to $26 \mathrm{mg} \mathrm{Fe} \mathrm{g}^{-1} \mathrm{FW}$, J. Blasco unpubl. data).

The aerobic oxidation of $\mathrm{C}_{\text {org }}$ lead to a decrease in pH (Fig. 8), likely shifting the balance between precipitation and dissolution to dissolution of carbonate minerals (Mucci et al. 2000). The decrease in $C_{\text {inor }}$ content of sediment during the first $3 \mathrm{~d}$ (Fig. 3C) was probably driven by the decrease in pore water $\mathrm{pH}$ (Fig. 8). This is a clear signal that macroalgal decomposition might transiently alter the capacity of intertidal sediment to sequester $\mathrm{C}$ in inorganic forms. The anaerobic oxidation of $\mathrm{C}_{\text {org }}$ by sulfate reduction should increase $\mathrm{pH}$ and alkalinity, increasing the saturation state of carbonates and favouring precipitation (Mucci et al. 2000). We observed a slight increase in $C_{\text {inorg }}$ from Day 3 that was coincident with a change in $\mathrm{pH}$ of the microcosm water column and within the sediment in light (Figs. 3C \& 8). Daily changes in $\mathrm{O}_{2}$ availability and $\mathrm{O}_{2}$ penetration depth in the sediment, together with the photosynthetically driven daily changes in $\mathrm{pH}$, likely affect the overall $\mathrm{C}_{\text {org }}$ and $\mathrm{C}_{\text {inorg }}$ preservation rates of decaying macroalgal blooms in intertidal sediments (Kristensen et al. 1995, Holmer 1999).

\section{Changes in the microphytobenthic community and fertilization}

The initial microphytobenthic biomass in the microcosm estimated by chl a concentration was in the low to middle range of published in situ values (Cahoon 1999). We observed an immediate transient decrease after the addition of macroalgal detritus (Fig. 9A). Below a dense macroalgal canopy, irradiance may be too low to support photosynthetic activity and therefore chlorophyll synthesis by the microphytobenthos (Sundbäck et al. 1996, Astill \& Lavery 2001). However, at the macroalgal detritus load used in our experiment, this only occurred in the covered patches (Fig. 7). In addition to a transient decrease in chl a concentration, we observed taxonomic changes in the microphytobenthic community not previously reported (Table 2). Microphytobenthos was slightly dominated by filamentous colonial Cyanobacteria like Leptolyngbya sp., Merismopedia sp. and Johannesbaptistia sp. These species are generally scarce in typical intertidal sediments, where benthic diatoms usually dominate the community due to a higher grazing resistance (Cahoon 1999, Garcia de Lomas et al. 2005). The relative increase of Cyanobacteria after the addition of macroalgal detritus was likely due to their higher resistance to anoxic conditions than diatoms (Cohen et al. 1986, De Wit et al. 1988) and their higher capacity for using organic substrates (Stal \& Moezelaar 1997). The environmental conditions were probably less favourable for diatom growth (Admiraal \& Peletier 1979), although the utilization of organic substrate by some diatoms has been reported as well (Nilsson \& Sundbäck 1996, Tuchman et al. 2006). In addition, low stoichiometric $\mathrm{Si}: \mathrm{N}$ and $\mathrm{Si}: \mathrm{P}$ ratios in the pore water were more favourable for Cyanobacteria. The degradation of macroalgal detritus further enriched the system in $\mathrm{N}$ and $\mathrm{P}$ in relation to $\mathrm{Si}$ availability. Likely, these conditions favoured further cyanobacterial growth and hence their dominance in the microbial community. Interestingly, the mesocosm shifted from being a net sink for $\mathrm{Si}$ to a net source (Fig. 5B), sug- 
gesting the existence of a net flux from the sediment to the water column that was not fully intercepted by the benthic diatom assemblage. The observed shift in the taxonomic composition of the microphytobenthic community might affect higher trophic levels. The degradation of macroalgal detritus in photic sediments released organic and inorganic compounds that provided energy and materials sources for the microbenthic community, leading in turn to the transient fertilization of the sediment. Increases in nutrients stimulated the phototrophic community, increasing photosynthetic activity and biomass.

Acknowledgements. We thank J. Vergara and A. Bartual theirs advice on pigment extraction, N. P. Revsbech for his comments on an early draft, and 2 anonymous referees for their comments and suggestions. The research was funded by grants REN 2002-01281/MAR and CTM 2006-04015 to A.C. from the Ministry of Education and Science (Spain).

\section{LITERATURE CITED}

Admiraal W, Peletier H (1979) Sulphide tolerance of benthic diatoms in relation to their distribution in an estuary. Br Phycol J 14:185-196

Astill H, Lavery PS (2001) The dynamics of unattached benthic macroalgal accumulations in the Swan-Canning estuary. Hydrol Process 15:2387-2399

Bennett A, Bogorad L (1973) Complementary chromatic adaptation in a filamentous blue-green alga. J Cell Biol 58:419-435

Boone DR, Castenholz RW (2001) Bergey's manual of systematic bacteriology. 2nd edn, Vol 1. The Archeae and the deeply branching and phototrophic Bacteria. Springer, New York

Boudreau BP (1997) Diagenetic models and their interpretation: modelling transport and reactions in aquatic sediments. Springer, Berlin

Bourgues S, Auby I, Wit R, Labourg PJ (1996) Differential anaerobic decomposition of seagrass (Zostera noltii) and macroalgal (Monostroma obscurum) biomass from Arcachon Bay (France). Hydrobiologia 329:121-131

Bourrelly P (1970) Les algues d'eau douce. Initiation à la systématique. I: Les algues bleues et rouges, les eugléniens, peridiniens et cryptomonadines. Boubée, Paris

Bourrelly P (1981) Les algues d'eau douce. Initiation à la systématique. III: Les algues jaunes et brunes. Chrysophycées, phéophycées, xanthophycées et diatomées. Boubée, Paris

Buchsbaum R, Valiela I, Swain T, Dzierzeski M, Allen SD (1991). Available and refractory nitrogen in detritus of coastal vascular plants and macroalgae. Mar Ecol Prog Ser 72:131-143

Cahoon LB (1999) The role of benthic microalgae in neritic ecosystem. Oceanogr Mar Biol Annu Rev 37:47-86

Canfield DE, Raiswell R, Bottrell J (1992) The reactivity of sedimentary iron minerals toward sulfide. Am J Sci 292:659-683

Castaldelli G, Welsh DT, Flachi G, Zucchini G, Colombo G, Rossi R, Fano EA (2003) Decomposition dynamics of the bloom forming macroalga Ulva rigida C.Agardh determined using a ${ }^{14} \mathrm{C}$-carbon radio-tracer technique. Aquat Bot 75:111-122
Cohen Y, Jorgensen BB, Revsbech NP, Poplawski R (1986) Adaptation to hydrogen sulfide of oxygenic and anoxygenic photosynthesis among Cyanobacteria. Appl Environ Microbiol 51:398-407

Corzo A, Niell FX (1992) Inorganic nitrogen metabolism in Ulva rigida illuminated with blue light. Mar Biol 112: $223-228$

Corzo A, Garcia de Lomas J, van Bergeijk SA, Luzon A, Mayayo MJ, Mata P (2005) Carbonate mineralogy along a biogeochemical gradient in recent lacustrine sediments of Gallocanta Lake (Spain). Geomicrobiol J 22:283-298

Dalsgaard T (2003) Benthic primary production and nutrient cycling in sediments with benthic microalgae and transient accumulation of macroalgae. Limnol Oceanogr 48:2138-2150

De Wit R, Van Boekel WHM, Van Gemerden H (1988) Growth of the cyanobacterium Microcoleus chthonoplastes on sulphide. FEMS Microbiol Ecol 53:203-209

Eyre BD, Ferguson AJP (2005) Benthic metabolism and nitrogen cycling in a subtropical east Australian estuary (Brunswick): temporal variability and controlling factors. Limnol Oceanogr 50:81-96

Gabrielson JO, Birch PB, Hamel KS (1983) Decomposition of Cladophora. Part II. In vitro studies of nitrogen and phosphorus regeneration. Bot Mar 25:173-179

Garcia de Lomas J, Corzo A, García C, van Bergeijk SA (2005) Microbenthos in a hypersaline tidal lagoon: factors affecting microhabitat, community structure and mass exchange at the sediment-water interface. Aquat Microb Ecol 38:53-69

Grasshoff K, Ehrhardt M, Kremling K (1983) Methods of sea water analysis. Verlag Chemie, Weinheim

Hayden HS, Blomster J, Maggs CA, Silva PC, Stanhope MJ, Waaland JR (2003) Linnaeus was right all along: Ulva and Enteromorpha are not distinct genera. Eur J Phycol 38:277-294

Holmer M (1999) The effect of oxygen depletion on anareobic organic matter degradation in marine sediment. Estuar Coast Mar Sci 48:383-390

Kamermans P, Malta EJ, Verschuure JM, Lentz LF, Schrijvers L (1998) Role of cold resistance and burial for winter survival and spring initiation of an Ulva spp. (Chlorophyta) bloom in a eutrophic lagoon (Veerse Meer lagoon, The Netherlands). Mar Biol 131:45-51

Kasten S, Jørgensen BB (2000) Sulfate reduction in marine sediments. In: Schultz HD, Zabel M (eds) Marine geochemistry. Springer, Bremen

Kristensen E, Ahmed SI, Devol AH (1995) Aerobic and anaerobic decomposition of organic matter in marine sediments: which is faster? Limnol Oceanogr 40:1430-1437

Kühl M, Steuckart C, Eicker G, Jeroschewski P (1998) A $\mathrm{H}_{2} \mathrm{~S}$ microsensor for profiling biofilms and sediments: application in an acidic lake sediment. Aquat Microb Ecol 15: 201-209

Li YH, Gregory S (1974) Diffusion of ions in deep-sea sediments. Geochim Cosmochim Acta 38:703-714

Lomstein BA, Guldberg LB, Neubauer ATA, Hansen J and others (2006) Benthic decomposition of Ulva lactuca: a controlled laboratory experiment. Aquat Bot 85:271-281

Middelburg JJ, Barranguet C, Boschker HTS, Herman PMJ, Moens T, Heip CHR (2000) The fate of intertidal microphytobenthos carbon: an in situ C-13-labeling study. Limnol Oceanogr 45:1224-1234

Mucci A, Sundby B, Gehlen M, Arakaki T, Zhong S, Silverberg $N$ (2000) The fate of carbon in continental shelf sediments of eastern Canada: a case of study. Deep-Sea Res II 47:733-760 
Nedergaard RI, Risgaard-Petersen N, Finster K (2002) The importance of sulfate reduction associated with Ulva lactuca thalli during decomposition: a mesocosm experiment. J Exp Mar Biol Ecol 275:15-29

Nilsson C, Sundbäck K (1996) Amino acid uptake in natural microphytobenthic assemblages studied by microautoradiography. Hydrobiologia 332:119-129

Pedersen AU, Berntsen J, Lomstein BA (1999) The effect of eelgrass decomposition on sediment carbon and nitrogen cycling: a controlled laboratory experiment. Limnol Oceanogr 44:1978-1992

Pierson B, Oesterle A, Murphy GL (1987) Pigments, light penetration, and photosynthetic activity in the multi-layered microbial mats of Great Sippewissett salt marsh, Massachusetts. Microb Ecol 45:365-376

Revsbech NP (1989) An oxygen microelectrode with a guard cathode. Limnol Oceanogr 34:474-478

Revsbech NP, Jørgensen BB, Blackburn TH, Cohen Y (1983) Microelectrode studies of photosynthesis and $\mathrm{O}_{2}, \mathrm{H}_{2} \mathrm{~S}$ and $\mathrm{pH}$ profiles of a microbial mat. Limnol Oceanogr 28: 1062-1074

Risgaard-Petersen N (2003) Coupled nitrification-denitrification in autotrophic and heterotrophic estuarine sediments: on the influence of benthic microalgae. Limnol Oceanogr 48:93-105

Rizzo WM, Dailey SK, Lackey GJ, Christian RR, Berry BE, Wetzel RL (1996) A metabolism-based trophic index for comparing the ecological values of shallow-water sediment habitats. Estuaries 19:247-256

Stal LJ, Moezelaar R (1997) Fermentation in cyanobacteria. FEMS Microbiol Rev 21:179-211

Strauss EA, Lamberti GA (2000) Regulation of nitrification in aquatic sediments by organic carbon. Limnol Oceanogr 45:1854-1859

Sundbäck K, Snoeijs P (1991) Effects of nutrient enrichment on microalgal community composition in a coastal shallow-water sediment system: an experimental study. Bot Mar 34:341-358

Editorial responsibility: Otto Kinne,

Oldendorf/Luhe, Germany
Sundbäck K, Carlson L, Nilsson C, Jönsson B, Wulff A, Odmark S (1996) Response of benthic microbial mats to drifting green algal mats. Aquat Microb Ecol 10:195-208

Sundbäck K, Linares F, Larson F, Wulff A (2004) Benthic oxygen fluxes along a depth gradient in a microtidal fjord: the role of denitrification and microphytobenthos. Limnol Oceanogr 49:1095-1107

Thinh LV (1983) Effect of irradiance on the physiology and ultrastructure of marine cryptomonad, Cryptomonas strain Lis (Cryptophyceae). Phycologia 22:7-11

Thompson RC, Tobin ML, Hawkins SJ, Norton TA (1999) Problems in extraction and spectrophotometric determination of chlorophyll from epilithic microbial biofilms: towards a standard method. J Mar Biol Assoc UK 79: 551-558

Tuchman NC, Schollet MA, Rier ST, Geddes P (2006) Differential heterotrophic utilization of organic compounds by diatoms and bacteria under light and dark conditions. Hydrobiologia 561:167-177

Underwood GJC, Kromkamp J (1999) Primary production by phytoplankton and microphytobenthos in estuaries. Adv Ecol Res 29:93-153

Valiela I, Teal JM, Allen SD, Van Etten R, Goehringer D, Volkmanm S (1985) Decomposition in salt marsh ecosystems: the phases and major factors affecting disappearance of above-ground organic matter. J Exp Mar Biol Ecol 89:29-54

Valiela I, McClelland J, Hauxwell J, Behr PJ, Hersh D, Foreman K (1997) Macroalgal blooms in shallow estuaries: controls and ecophysiological and ecosystem consequences. Limnol Oceanogr 42:1105-1118

Viaroli P, Azzoni R, Bartoli N (2001) Evolution of the trophic conditions and dystrophic outbreaks in the Sacca di Goro lagoon (Northern Adriatic Sea). In: Faranda FM (ed) Structure and process in the Mediterranean ecosystems. Springer-Verlag, Milan, p 340-355

Williams SL (1984) Decomposition of the tropical macroalga Caulerpa cupressoides (West) C. Agardh: field and laboratory studies. J Exp Mar Biol Ecol 80:109-124

Submitted: April 13, 2007; Accepted: October 17, 2007

Proofs received from author(s): March 7, 2008 